\title{
Analisis dan Redesign Kekuatan Struktur pada Girder Overhead Crane 6.3 Ton
}

\author{
Ayzam Sunainah dan I Nyoman Sutantra \\ Departemen Teknik Mesin, Fakultas Teknologi Industri, Institut Teknologi Sepuluh Nopember (ITS) \\ e-mail: tantra@me.its.ac.id
}

\begin{abstract}
Abstrak-Pada era globalisasi ini, menurut data BPS Statistik Industri Manufaktur dari tahun 2013 hingga 2015 terdapat kenaikan pada jumlah industri manufaktur yang ada di Indonesia. Overhead crane merupakan crane yang sering digunakan di workshop industri manufaktur sebagai alat bantu untuk penataan barang, proses produksi, serta perbaikan produk. Karena perannya yang sangat penting, maka dari itu diperlukan overhead crane yang mampu digunakan sesuai kebutuhan, aman, dan tahan lama atau tidak mudah rusak, sehingga biaya yang diperlukan lebih ekonomis. Pada penelitian tugas akhir ini, akan dilakukan analisis kekuatan struktur overhead crane dengan mensimulasikan pada softwere berbasis metode elemen hingga (finite element analysis) serta perhitungan umurfatigue. Sebelum simulasi dilakukan, akan dibuat pemodelan 3D girder kemudian dimasukkan gaya-gaya yang bekerja pada crane yaitu, gaya berat, gaya angkat, dan gaya ayun beban. Gaya-gaya yang diaplikasikan akan diposisikan pada $x=3.5 \mathrm{~m}, x=10.788 \mathrm{~m}$, dan $x=18.576 \mathrm{~m}$. Untuk analisis fatigue akan dilakukan pengolahan data hasil simulasi tegangan untuk mengetahui umur siklus crane. Berdasarkan hasil tersebut akan dilakukan desain ulang untuk mendapatkan struktur yang diinginkan yaitu, berupa struktur yang diharapkan kuat terhadap beban statis dan dinamis, mempunyai umur siklus yang lama, serta mempunyai distribusi tegangan yang lebih merata. Hasil dari penelitian ini tegangan von Mises yang mempunyai stress range dan mean stress terbesar ada pada siklus kedua yaitu pada saat posisi pembebanan di $x=10,788$ m. Tegangan yang dimiliki oleh siklus tersebut adalah tegangan maksimum 230,393 MPa dan tegangan minimum 79,482 MPa. Tegangan ini sudah aman menurut Soderberg failure line tetapi belum aman dengn angka keamanan 1,5 dan memiliki usia fatigue 644409 siklus. Sedangkan tegangan pada girder setelah redesign pada siklus yang sama mempunyai tegangan maksimum 204,589 MPa dan tegangan minimum 70,055 MPa. Tegangan ini sudah aman menurut angka keamanan 1,5 dan mempunyai umum 91033 siklus.
\end{abstract}

Kata Kunci-fatigue, kekuatan struktur, metode elemen hingga, overhead crane.

\section{PENDAHULUAN}

$\mathrm{S}^{\mathrm{E}}$ EMAKIN berkembangnya zaman, produksi yang dilakukan oleh suatu industridituntut semakin cepat dengan kapasitas yang semakin besar. Oleh karena itu, dalam dunia industri sekarang dibutuhan alat bantu untuk memindahkan dan mengangkat barang mulai dari yang sederharana (konvensional) sampai yang menggunakan teknologi otomatis. Menurut data BPS Statistik Industri Manufaktur dari tahun 2013 hingga 2015 terdapat kenaikan pada jumlah industri manufaktur yang ada di Indonesia seperti [1][2], dan [3]. Saat ini, overhead crane merupakan crane yang sering digunakan di workshop industri manufaktur sebagai alat bantu untuk penataan barang di gudang, pemindahkan barang dari satu workstation ke workstation berikutnya, proses produksi, serta perbaikan produk. Sehingga crane memiliki peran besar dalam produktifitas industri manufaktur. Namun menurut Occupational Safety and Health Administration (OSHA) $80 \%$ penyebab utamanya adalah akibat overloading. Penggunaan komponen yang cacat, pengangkatan beban melibihi kapasitas, menyeret beban, dan beban dinamis yang tidak diperhitungkan seperti swinging dan sudden drop merupakan faktor-faktor yang menyebabkan terjadinya overloading [4]. Jika terjadi kegagalan pada struktur crane maka dapat menyebabkan kerusakan irreversible dan membahayakan para pekerja. Hal tersebut tentunya akan memakan biaya yang besar, sehingga diperlukan overhead crane yang mampu digunakan sesuai kebutuhan, aman, dan tahan lama atau tidak mudah rusak, sehingga biaya yang diperlukan lebih ekonomis.

Berdasarkan hal diatas, maka perlu diketahui kekuatan struktur dan umur fatigue pada crane yang sudah ada kemudian dilakukan desain ulang untuk mendapatkan struktur yang lebih kuat terhadap beban statis dan dinamis, mempunyai distribusi tegangan yang lebih merata sehingga mempunyai umur siklus yang lama.

\section{URAIAN PENELITIAN}

Penelitian tugas akhir ini dilakukan untuk melihat kekuatan struktur,defleksi dan tegangan, dari pembeban dinamis pada girder over head crane yaitu, serta mengetahui umur fatigue yang akibat pembebanan tersebut. Dari hasil analis is simulasi tersebut kemudian dilakukan desain ulang pada girder overhead crane dengan kapasitas yang sama, tetapi mempunyai kekuatan struktur dan usia fatigue yang lebih baik.

Gaya-gaya yang bekerja pada girder tidak hanya gaya berat maksimum (berat girder, berat hoist, dan berat SWL) akan tetapi juga gaya angkat dan gaya ayun.

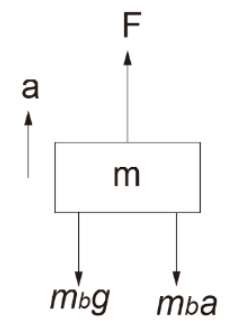

Gambar 1. Free body diagram saat beban diangkat. 


$$
\begin{aligned}
& \sum F=m a \\
& F=m_{b} g+m_{b} a \\
& F=W_{b}+m_{b} a
\end{aligned}
$$

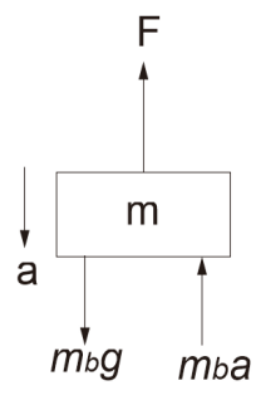

Gambar 2. Free body diagram gaya saat beban diturunkan.

$$
F=W_{b}-m_{b} a
$$

Dimana :

$\mathrm{F}=$ gaya angkat $(\mathrm{N})$

$\mathrm{W}_{\mathrm{b}}=$ gaya berat benda $(\mathrm{N})$

$\mathrm{m}_{\mathrm{b}}=$ massa benda $(\mathrm{kg})$

$\mathrm{g}=$ percepatan gravitasi $\left(\mathrm{m} / \mathrm{s}^{2}\right)$

$\mathrm{a}=$ percepatan gerak $\left(\mathrm{m} / \mathrm{s}^{2}\right)$

Untuk mencari percepatan pada saat pengangkatan dan penurunan benda dapat menggunakan persamaan berikut:

$$
V^{2}=V_{0}^{2}+2 a s
$$

Dimana :

$\mathrm{V}=$ kecepatan angkat $(\mathrm{m} / \mathrm{s})$

$\mathrm{V}_{0}=$ kecepatan angkat awal $(\mathrm{m} / \mathrm{s})$

$\mathrm{s}=$ jarak perpindahan $(\mathrm{m})$

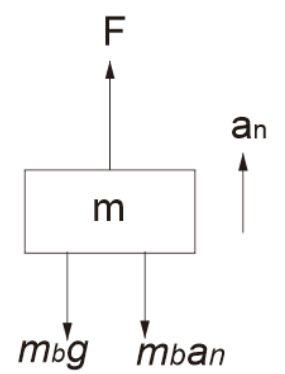

Gambar 3. Free body diagram saat benda mengayun.

$$
\begin{aligned}
& \mathrm{a}_{\mathrm{n}}=\omega^{2} R \\
& \omega=\frac{v}{R} \\
& \mathrm{~F}=m_{b} g+m_{b} a_{n} \\
& \text { Dengan : } \\
& \mathrm{F}=\text { gaya total }(\mathrm{N}) \\
& \omega=\text { kecepatan rotasi }(\mathrm{rad} / \mathrm{s}) \\
& \mathrm{R}=\text { panjang tali yang mengayun (m) } \\
& \mathrm{a}_{\mathrm{n}}=\text { percepatan normal }\left(\mathrm{m} / \mathrm{s}^{2}\right)
\end{aligned}
$$

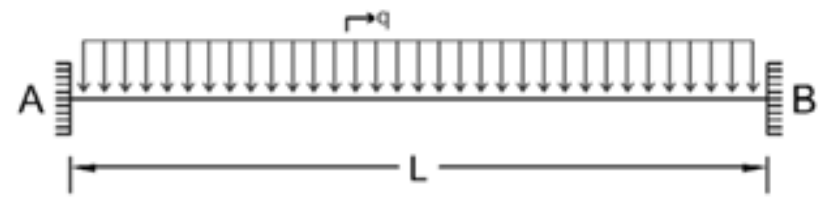

Gambar 4. Model tumpuan jepit dan gaya distribusi rata [5].

$$
\begin{aligned}
& M_{B A}=\frac{q L^{2}}{12} \\
& M_{A B}=M_{B A}
\end{aligned}
$$

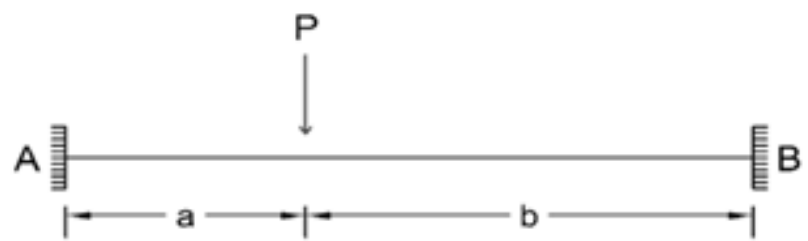

Gambar 5. Model tumpuan jepit dan gaya terpusat [5].

$$
\begin{aligned}
& M_{B A}=\frac{P b a^{2}}{L^{2}} \\
& M_{B A}=\frac{P b a^{2}}{L^{2}}
\end{aligned}
$$

Gaya reaksi pada girder crane dapat dicari menggunakan persamaan berikut:

$$
\begin{aligned}
& R_{A}=\frac{P b}{L} \\
& R_{B}=\frac{P a}{L}
\end{aligned}
$$

Tegangan normal dapat dicari dengan persamaan berikut:

$$
\sigma=M \frac{y}{I}
$$

Tabel 1.

Spesifikasi overhead crane [6]

\begin{tabular}{lll}
\hline \hline Type & $\begin{array}{c}\text { MHE - Demag Single Girder Overhead } \\
\text { Travelling Crane }\end{array}$ \\
\hline Safe working load & $6.3 \mathrm{Ton}$ \\
Span & $22 \mathrm{~m}$ \\
Main girder & $21,576 \mathrm{~m}$ & \\
Hook path & $8 \mathrm{~m}$ & \\
Main hoisting speed & $4,5 / 0,8 \mathrm{~m} / \mathrm{min}$ & $0,0937 \mathrm{~m} / \mathrm{s}$ \\
Cross travel speed & $30 / 5 \mathrm{~m} / \mathrm{min}$ & $0,1 \mathrm{~m} / \mathrm{s}$ \\
Long travel speed & $40 / 10 \mathrm{~m} / \mathrm{min}$ & $0,067 \mathrm{~m} / \mathrm{s}$ \\
Crane operation & Indoor & \\
Deflection design & Min. L/750 \\
\hline \hline
\end{tabular}

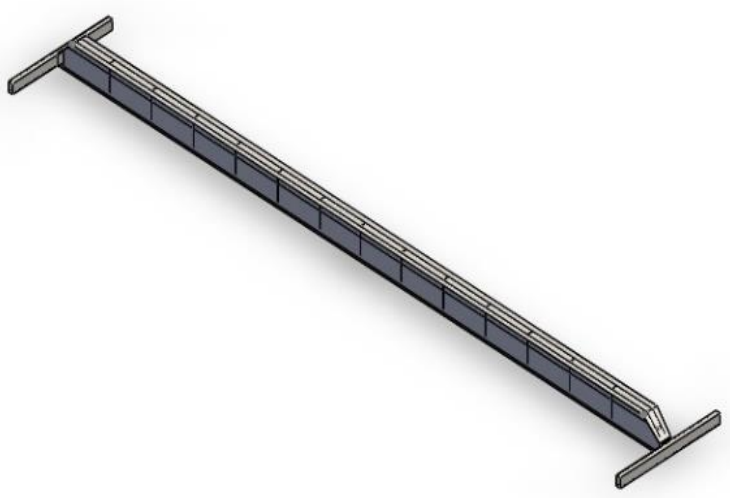

Gambar 6. Pemodelan 3D overhead crane dengan Solidworks.

Setelah dilakukan pemodelan struktur secara 3D kemudian dapat dimasukkan properti material menurut standar DIN 15018 yaitu ST37-2, kondisi batas atau boundary condition yaitu posisi tumpuan struktur, gaya-gaya pada girder crane yang akan diaplikasikan pada $x=3.5 \mathrm{~m}, \mathrm{x}=10.788 \mathrm{~m}, \mathrm{x}=3.5 \mathrm{~m}$, dan yang terakhir dilakukan mesh\&run untuk melihat defleksi (displacecment) dan tegangan yang ada. Pemodelan dan simulasi dilakukan degan software berbasis metode elemen hingga. 


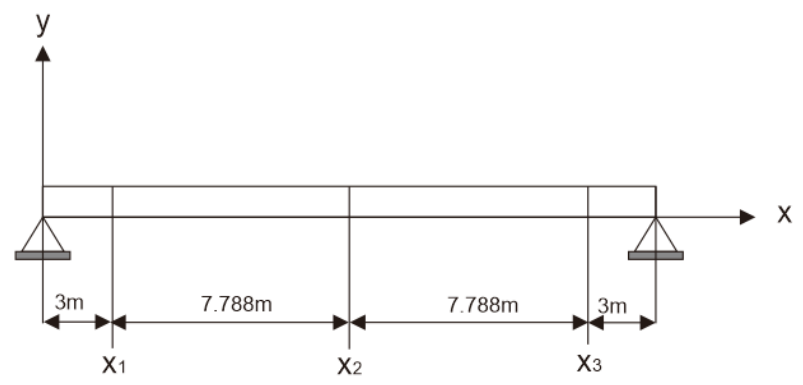

Gambar 7. Posisi $\mathrm{x}$ terhadap panjang girder $\mathrm{L}$.

Pergantian posisi ini juga untuk menentukan tegangan maksimum dan minimum tiap siklus kerja crane yang telah ditentukan. Siklus 1 yaitu pada posisixl beban SWL diangkat kemudian digerakkan secara cross travel dan long travel sesuai kebutuhan kemudian diturunkan. Siklus 2 yaitu pada posisi x2 yaitu L/2 beban diperlakukan sama dengan siklus 1 . Siklus 3 berada pada posisi $\mathrm{x} 3$ dengan perlakukan pembebanan sama dengan siklus 1.

Setelah mengetahui tegangan maksimum dan minimum tiap siklus kemudian data tersebut diolah secara terminologi beban siklus seperti dibawah ini.

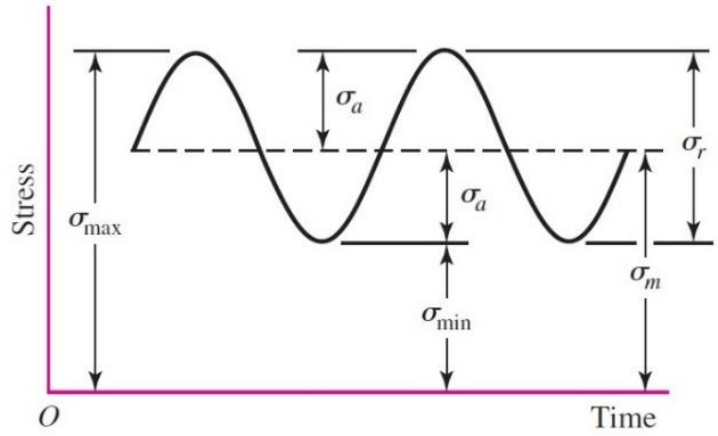

Gambar 8. Stress vs time sinusoidal fluctuating stress [7].

Pengertian beberapa istilah pada teori fatigue [8]:

1. Cycle $(\mathrm{N})$ adalah siklus dimana beban bermula dari posisi rata-rata pada waktu tertentu dan kembali ke posisi yang sama setelah beberapa interval waktu.

2. Maximum stress $\left(\sigma_{\max }\right)$ merupakan nilai tegangan maksimum yang terjadi pada keseluruhan suatu material ketika pembebanan.

3. Minimum stress $\left(\sigma_{\min }\right)$ merupakan nilai tegangan maksimum yang terjadi pada keseluruhan suatu material ketika pembabanan.

4. Mean stress $\left(\sigma_{\mathrm{m}}\right)$

$\sigma_{m}=\frac{\sigma \max +\sigma \min }{2}$

5. Stress range $\left(\sigma_{\mathrm{r}}\right)$

$\sigma_{r}=\sigma_{\max }-\sigma_{\min }$

6. Amplitude of stress $\left(\sigma_{\mathrm{a}}\right)$

$\sigma_{a}=\frac{\sigma \max -\sigma \min }{2}$

7. $\quad$ Stress ratio $(\mathrm{R})$

$R=\frac{\sigma \min }{\sigma \max }$

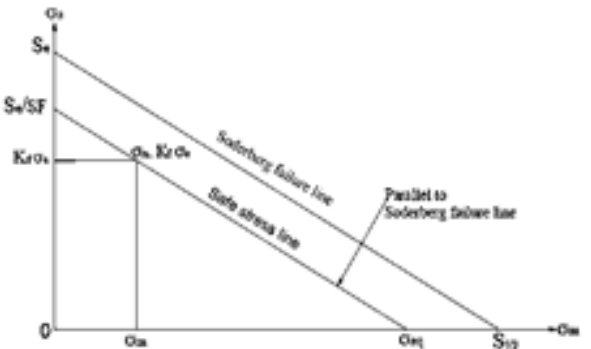

Gambar 9. Equivalent Stress pada Soderberg Line.

Keterangan :

$\mathrm{Kf}=$ fatigue stress concentration factor

$\mathrm{Se}=$ endurance limit $(\mathrm{MPa})$

$\mathrm{Syp}=$ yield point strength $(\mathrm{MPa})$

$\sigma_{\mathrm{eq}}=$ tegangan ekivalen $(\mathrm{MPa})$

$\sigma_{\text {eq }}=\frac{\mathrm{S}_{\mathrm{yp}}}{\text { Safety factor }}$

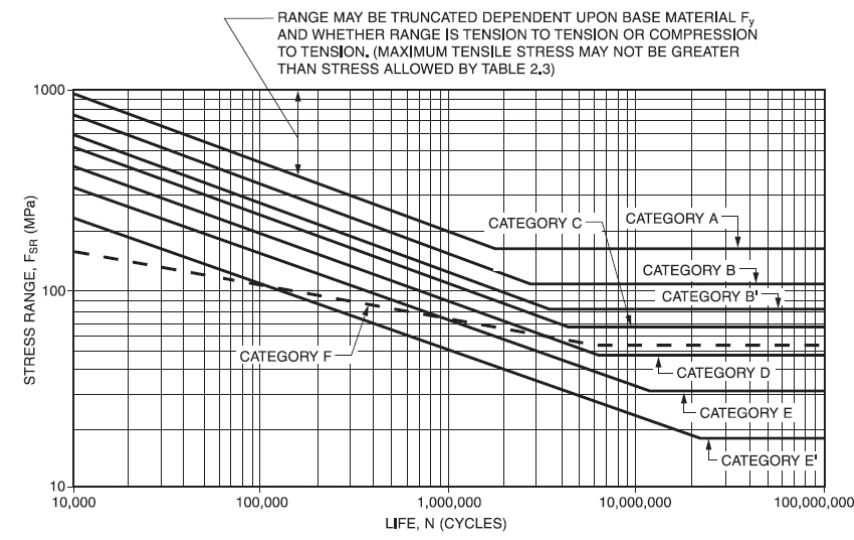

Gambar 10. Kurva S-N berdasarkan AWS D1.1, 2002 section 2 non tubular joints [8].

Secara matematis kurva diatas dapat dibaca menggunakan persamaan berikut:

$$
\begin{aligned}
\log \mathrm{N} & =\log \log A-m \log \Delta \sigma \\
\mathrm{N} & =\frac{A}{\Delta \sigma^{m}}
\end{aligned}
$$

Dimana:

$\mathrm{N}=$ jumlah cycle

$\mathrm{A}=$ parameter kurva $\mathrm{S}-\mathrm{N}$ berdasarkan data tabel 2

$\Delta \sigma=$ rentang tegangan

$\mathrm{m}$ = slope inverse negatif. Bernilai 3 untuk semua kategori joint-stress, terkecuali kategori $\mathrm{F}$ dengan $\mathrm{m}$ $=5.8$

Tabel 2.

Korespondensi kategori stress dengan parameter kurva S-N untuk sambungan non-tubular $[8]$

\begin{tabular}{cccc}
\hline \hline Stress Category & $\mathrm{S}_{\mathrm{rl}}(\mathrm{ksi})$ & $\mathrm{A}$ & $\mathrm{m}$ \\
\hline $\mathrm{A}$ & 24 & $276 \times 10^{\circ}$ & 3 \\
$\mathrm{~B}$ & 16 & 117 & 3 \\
$\mathrm{C}$ & 12 & 67,5 & 3 \\
$\mathrm{D}$ & 10 & 43,9 & 3 \\
$\mathrm{E}$ & 7 & 20 & 3 \\
$\mathrm{~F}$ & 5 & 10,2 & 3 \\
$\mathrm{E}$ & 3 & 4,3 & 3 \\
$\mathrm{~F}$ & 8 & 68,5 & 5,8 \\
\hline \hline
\end{tabular}




\section{HASIL DAN ANALISIS}

\section{A. Hasil Simulasi Statis Girder Overhead Crane}

Tabel 3 .

Hasil simulasi defleksi ( $\mathrm{mm})$

\begin{tabular}{lllll}
\hline \hline Siklus & $\begin{array}{l}\text { defleksi } \\
\text { dengan gaya } \\
\text { angkat }\end{array}$ & $\begin{array}{l}\text { defleksi } \\
\text { dengan gaya } \\
\text { ayun }\end{array}$ & $\begin{array}{l}\text { defleksi } \\
\text { dengan gaya } \\
\text { berat hoist }\end{array}$ & $\begin{array}{l}\text { Titik } \\
\text { defleksi } \\
\text { maksimum }\end{array}$ \\
\hline siklus 1 & 6,89828 & 6,90163 & 3,68838 & 30612 \\
siklus 2 & 13,4222 & 13,4317 & 4,11421 & 86353 \\
siklus 3 & 6,90776 & 6,91112 & 3,68882 & 77360 \\
\hline \hline
\end{tabular}

Tabel 4.

Hasil simulasi tegangan von Mises (MPa)

\begin{tabular}{lllll}
\hline \hline \multirow{2}{*}{ Siklus } & $\begin{array}{l}\text { Tegangan } \\
\text { (MPa) dengan } \\
\text { gaya angkat } \\
\text { 66069 N }\end{array}$ & $\begin{array}{l}\text { Tegangan } \\
\text { (MPa) dengan } \\
\text { gaya ayun } \\
66132 \mathrm{~N}\end{array}$ & $\begin{array}{l}\text { Tegangan } \\
\text { (MPa) dengan } \\
\text { gaya berat } \\
\text { hoist 4238 N }\end{array}$ & $\begin{array}{l}\text { Titik } \\
\text { kritis }\end{array}$ \\
\hline siklus 1 & 206,618 & 206,751 & 76,8155 & 5316 \\
siklus 2 & 230,235 & 230,393 & 79,482 & 5850 \\
siklus 3 & 210,496 & 210,628 & 78,2105 & 5850 \\
\hline \hline
\end{tabular}

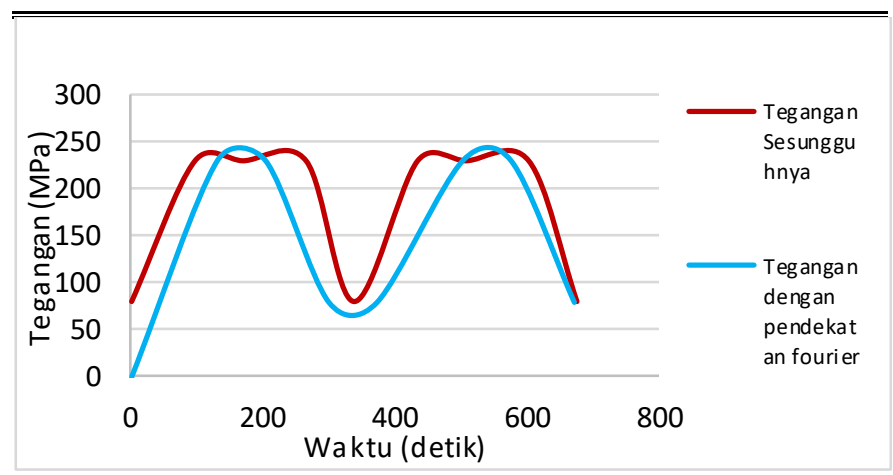

Gambar 11. Grafik waktu vs tegangan pada siklus ke 2 .

Tabel 5.

Hasil perhitungan mean stress

\begin{tabular}{llll}
\multicolumn{3}{c}{ Hasil perhit ungan mean stress } \\
\hline \hline Siklus & \multicolumn{2}{l}{$\begin{array}{l}\text { Tegangan von Mises } \\
(\mathrm{MPa})\end{array}$} & $\begin{array}{l}\text { Mean stress } \\
\text { (MPa) }\end{array}$ \\
\cline { 2 - 4 } & $\max$ & $\min$ & 141,78325 \\
\hline Siklus 1 & 206,751 & 76,8155 & 154,9375 \\
Siklus 2 & 230,393 & 79,482 & 144,41925 \\
Siklus 3 & 210,628 & 78,2105 & 125 \\
\hline \hline
\end{tabular}

Tabel 6.

Hasil perhitungan alternating stress

\begin{tabular}{llll}
\hline \hline \multirow{2}{*}{ Siklus } & \multicolumn{2}{l}{ Tegangan von Mises (MPa) } & Alternating stress \\
\cline { 2 - 3 } & $\max$ & $\min$ & 64,96775 \\
\hline Siklus 1 & 206,751 & 76,8155 & 75,4555 \\
Siklus 2 & 230,393 & 79,482 & 66,20875 \\
Siklus 3 & 210,628 & 78,2105 & \\
\hline \hline
\end{tabular}

Setelah mendapatkan hasil perhitungan tegangan rata-rata dan tegangan alternate (amplitudo), kemudian hasil tersebut diplotkan pada diagram Soderberg failure line dengan angka keamanan 1,5 .

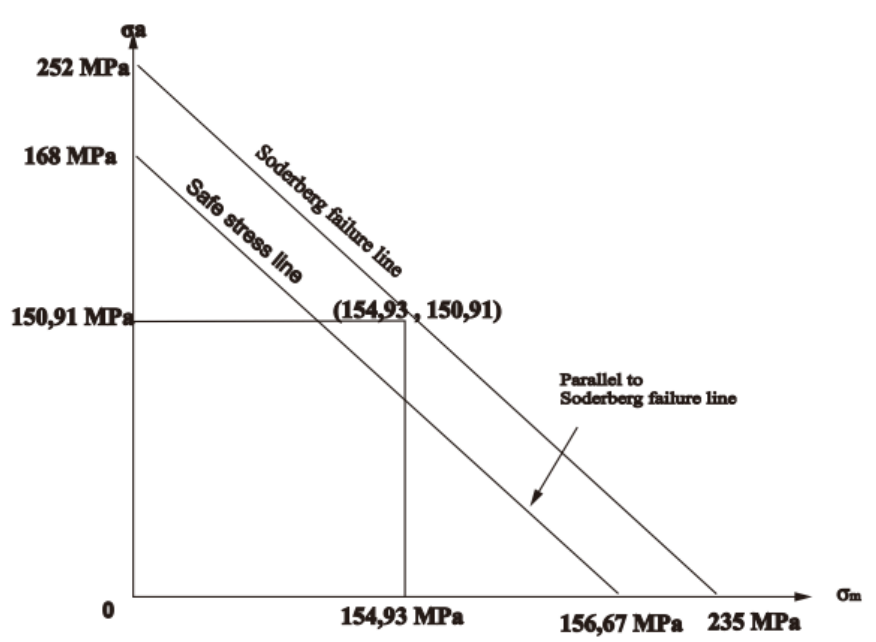

Gambar 12. Posisi tegangan pada grafik Soderbergfailure line.

Pada Soderberg failure line dapat dilihat bahwa tegangan masih belum aman dengan angka keamanan 1,5.

Untuk menghitung umur siklus crane, akan dilihat berdasarkan kategori tegangannya dengan tabel 2.5 , plot kurva S-N untuk crane ini menurut gambar 2.17 adalah B' dengan A $=67,5 \times 10^{8}$ dan $\mathrm{m}=3$ sehingga $\mathrm{N}$ dapat diketahui sebagai berikut. Rentang tegangan $\Delta \sigma$ diubah dari satuan MPa ke Ksi terlebih dahulu. Sehingga didaptkan umur siklus fatigue adalah 644409 siklus. Hasil tersebut menunjukkan umur siklus yang dimiliki girder crane tersebut sudah lebih baik pada umur siklus desain minimum sesuai standar yaitu $2.10^{4}$ sampai dengan $2.10^{5}$

\section{B. Hasil Redesign Girder Overhead Crane}

Titi-titik kritis yang ditunjukkan pada simulasi statis sebelumnya berada pada ujung-ujung web plate oleh karena itu dilakukan redesign berupa penambahan plat yang diletakkan pada posisitersebut.

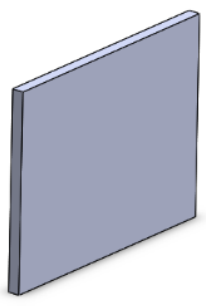

Gambar 13. Profil 3D part redesign.

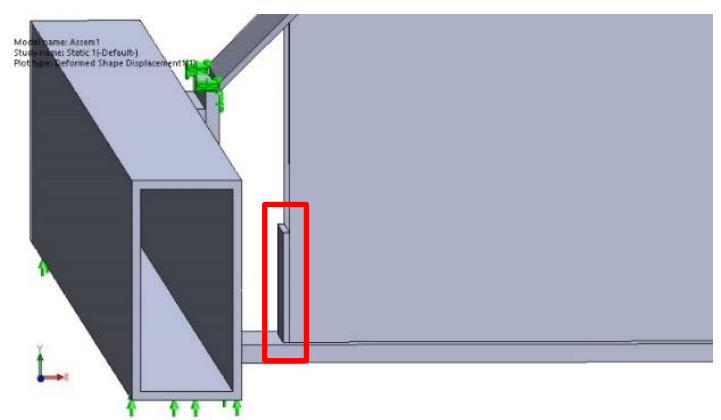

Gambar 14. Posisi plat redesign.

Kemudian dilakukan simulasi dengan langkah-langkah yang sama seperti sebelumnya, sehingga didapatkan hasil sebegai berikut. 


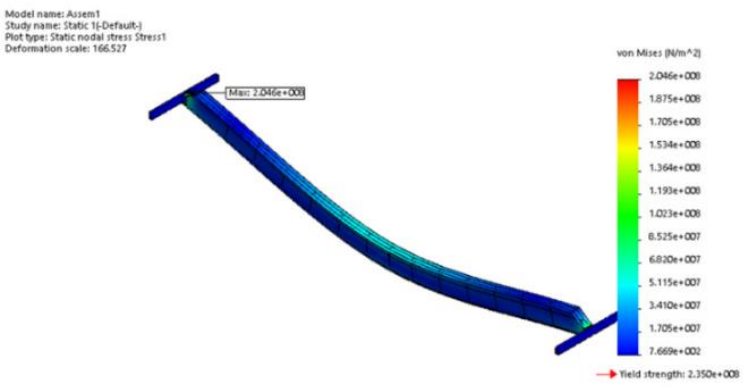

Gambar 15. Distribusi tegangan pada part redesign siklus 2 gaya ayun.

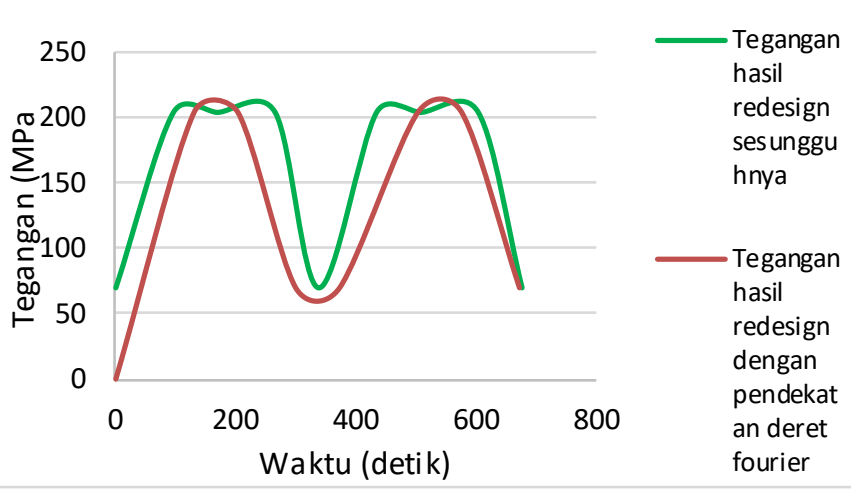

Gambar 16. Grafik waktuvs tegangan setelah dilakukan redesign.

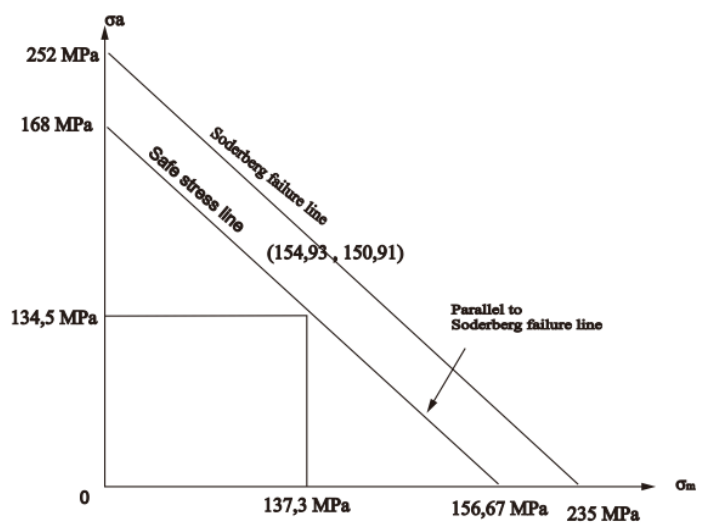

Gambar 17. Grafik Soderbergfailure line setelah redesign.

Pada Soderberg failure line dapat dilihat bahwa tegangan sudah aman dengan angka keamanan 1,5.

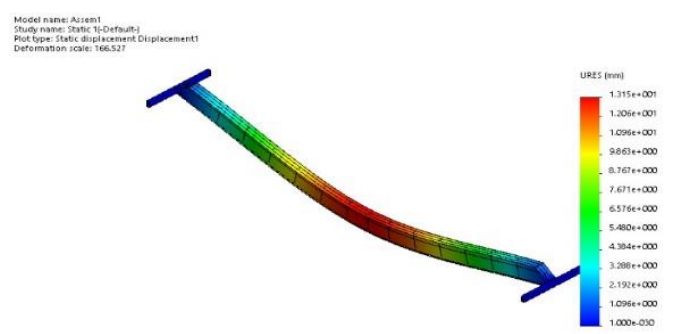

Gambar18. Defleksi pada part redesign.
Untuk perhitungan umur siklus sesudah dilakukan redesign pada girder didapatkan stress range $=134,5 \mathrm{MPa}=19,5 \mathrm{ksi}$. Sehingga didapatkan umur siklus fatigue 910332 siklus.

\section{Perbandingan Hasil Kekuatan Struktur dan Umur Fatigue}

Perbandingan kedua hasil kekuatan struktur dan umur fatigue pada girder overhead crane sebelum dan setelah redesign dapat dilihat pada tabel dibawah ini.

Tabel 5 .

Perbandingan hasil analisis kekuatan struktur dan fatigue sebelum dan sesudah redesign

\begin{tabular}{llll}
\hline \hline $\begin{array}{l}\text { Hasil yang } \\
\text { dibandingkan }\end{array}$ & Satuan & $\begin{array}{l}\text { Sebelum } \\
\text { redesign }\end{array}$ & Setelah redesign \\
\hline $\begin{array}{l}\text { Tegangan } \\
\text { maksimum }\end{array}$ & $\mathrm{MPa}$ & 230,393 & 79,482 \\
$\begin{array}{l}\text { Tegangan } \\
\text { minimum }\end{array}$ & $\mathrm{MPa}$ & 204,589 & 70,055 \\
$\begin{array}{l}\text { Defleksi } \\
\text { Analisa kegagalan }\end{array}$ & - & $\begin{array}{l}13,4317 \\
\text { Gagal menurut }\end{array}$ & $\begin{array}{l}\text { Aman menurut } \\
\text { angka keamanan }\end{array}$ \\
& & 1,5 & 1,5 \\
Umurfatigue & cycle & 644409 & 910332 \\
\hline \hline
\end{tabular}

Dari tabel 5 dapat diketahui bahwa hasil redesign sudah lebih baik dari segi kekuatan dan umur fatigue. Untuk kekuatan struktur, meskipun gaya yang bekerja pada girder mempunyai nilai yang sama akan tetapi tegangannya baik maksimum maupun minimum yang terjadi menurun setelah dilakukan desain ulang. Begitu pula dengan defleksi atau displacement, meskipun tidak berbeda jauh tetapi nilainya juga menurun. Karena penurunan tegangan rata-rata dan alternate (amplitudo), maka pada analisa kegagalan Soderberg line yang awalnya masih dianggap gagal dengan angka keamanan 1,5 setelah desain ulang sudah dianggap aman dengan angka keamanan 1,5 dan hasil perhitungan umur fatigue juga bertambah.

\section{KESIMPULAN}

Berdasarkan hasil simulasi dan pengolahan data dari penelitian overhead crane single girder ini, tugas akhir ini dapat disimpulkan:

1. Tegangan von Mises terbesar terdapat pada siklus ke 2 dengan gaya ayun yaitu 230,393 MPa sedangan tegangan terkecil pada siklus yang sama yaitu pada saat beban SWL sudah diturunkan mempunyai nilai 79,482 MPa. Sehingga mean stress yang didapatkan adalah 154,94 MPa dan stress range sebesar 150,91 MPa. Pada saat diaplikasikan pada grafik Soderberg failure line diketahui bahwa tegangan sudah aman berdasarkan garis tersebut akan tetapi masih dianggap gagal dengan angka kemanan 1,5.

2. Usia fatigue pada yang didapatkan dari hasil perhitungan terminologi bebansiklus adalah 644409 cycle, sehingga sudah dapat dikatakan aman karena sudah melebihi umur desain minimum yang ditentukan.

3. Redesign berupa plat yang diletakkan pada titik kritis yang ditunjukkan oleh distribusi tegangan dan umur. Tegangan maksimum yang terjadi adalah 204,589 MPa dan tegangan minimumnya adalah 70,055 $\mathrm{MPa}$. Dengan adanya 
redesign mampu mengurangi stress range yaitu menjadi 134,53 $\mathrm{MPa}$ juga mengurangi mean stress menjadi 137,332 $\mathrm{MPa}$,sehingga mampu menambah fatigue life hingga 910332 cycle. Tegangan yang dihasilkan dari redesign girder ini sudah mampu berada di bawah Soderberg failure line dengan angka keamanan 1,5.

4. Defleksi yang didapatkan dari hasil simulasi sebelum dan sesudah redesign yaitu, $13,4317 \mathrm{~mm}$ dan $13,15 \mathrm{~mm}$. Kedua nilai defleksi ini masih jauh dengan defleksi maksimum ijin yaitu 28,768 $\mathrm{mm}$ sehingga masih tergolong aman.

\section{DAFTAR PUSTAKA}

Manufaktur Indonesia 2013,”Jakarta, 2013.

[2] Sub Direktorat Statistik Industri Besar dan Sedang, "Statistik Industri Manufaktur Indonesia 2014,” Jakarta, 2014.

[3] Sub Direktorat Statistik Industri Besar dan Sedang, "Statistik Industri Manufaktur Indonesia 2015," Jakarta, 2015.

[4] K. Harman, "The Three most Common Overhead Crane Problems," $2014 . \quad$ [Online]. Available: http://www.spanco.com/blog/entry/overhead-crane-safetythreemajor-hazards-and-preventative-measures.

[5] Fulan 112 Business and Sharing, "Tabel Momen Primer," 2015. .

[6] Demagcranes.us, "Demag Standard Cranes." [Online]. Available: http://www.demagcranes.us/files/content/users/konstantinovsky/file s/22999649d0609 Demag Standard Cranes.pdf. [Accessed: 10-Nov2017].

[7] G. J. K. N. Richard and S. Budynas, MechanicalEngineering Design. New York: Mc Graw Hill, 2011.

[8] P. R. Permana, "Analisis Kekuatan Struktur dan Estimasi Fatigue Life Pada Konst ruksi Container Crane Tipe RTGBerkapasitas SWL 35 Ton," Surabaya, 2015. 